\title{
THE EFFECT OF PACKAGING TYPE AND STORAGE TEMPERATURE ON THE SHORT TERM STABILITY OF ELECTROLYTIC CONDUCTIVITY REFERENCE MATERIALS
}

\author{
AYU HINDAYANI ${ }^{1}$, OMAN ZUAS ${ }^{* 1}$, NURYATINI HAMIM ${ }^{1}$ \\ ${ }^{I}$ Chemical Metrology, Centre for Research and Human Resources Development \\ (PUSRISBANG), National Standardization Agency of Indonesia (BSN), Kawasan \\ PUSPIPTEK SNSU Building 420, Serpong 15314, Tangerang Selatan - Banten, Indonesia
}

\begin{abstract}
In this work, monitoring the effect of packaging type and storage temperature on the short term stability of calibration standard solution $\mathrm{KCl} 1 \mathrm{M}$ were conducted. The $\mathrm{KCl}$ $1 \mathrm{M}$ were packaged in two types of packaging i.e., high-density polyethylene (HDPE) and glass bottle. The effects of packaging type and storage temperature were monitored for four weeks at $25^{\circ} \mathrm{C}$ and $40{ }^{\circ} \mathrm{C}$. The conductivity values of $\mathrm{KCl} 1 \mathrm{M}$ in the HDPE and glass bottle were $111.61 \mathrm{mS} / \mathrm{cm}$ and $111.62 \mathrm{mS} / \mathrm{cm}$, respectively. The results indicated that the $\mathrm{KCl} 1 \mathrm{M}$ solution at $25^{\circ} \mathrm{C}$ in both HDPE and glass bottle were found to be good in short term stability and there was no significant different between the two packaging types. At temperature of 40 ${ }^{\circ} \mathrm{C}$, however, short term stability of the $\mathrm{KCl} 1 \mathrm{M}$ in a glass bottle was better than the HDPE bottle.
\end{abstract}

Keywords: chemical metrology, calibration, homogeneity, primary standard solution, traceability.

\section{INTRODUCTION}

Reference material (or RM in short) refers to sufficiently homogeneous and stable materials with respect to one or more specified properties, which has been established to be fit for its intended use in a measurement process [1]. The RM plays an important role in the quality control of measurements, especially for validation of methods, instrument calibration, and estimation of uncertainty [2]. Several types of RM may include a pure substance, standard solution, gas mixtures, matrix RM and physico-chemical RM with their specific intended use [3]. The RM are also classified based on their measurement method and it may include primary, secondary, and in-house RM. The primary RM refers to any RM measured by the primary method and directly traceable to the International System of Units (SI). The secondary RM is defined as the RM that measured by the secondary method and traceable to primary RM. While in-house or working RM is an RM that is measured by the working method and traceable to secondary RM [2].

In Indonesia, the availability of RM is available with a very limited number. General speaking, the RM is only available from overseas countries by importing them and it is costly and time-consuming. In such a condition, therefore, developing and producing the RM at the local level becomes very important and can be an alternative to address the local needs. Electrochemistry laboratory as part of chemical metrology Indonesia has started to be developed the production of RM, especially in electrolytic conductivity (or EC in short) measurement in the range of $111 \mathrm{mS} / \mathrm{cm}$. The RM was prepared from KCl $1 \mathrm{M}$ solution and traceable to National Metrology of Denmark

\footnotetext{
${ }^{*}$ Correspondence author: oman@bsn.go.id

(C) 2021 Alma Mater Publishing House
} 
(DFM, Danish Fundamental Metrology). This RM can be used as a standard solution to calibrate the conductivity meter in monitoring the quality of seawater [4].

The EC value of $\mathrm{KCl} 1 \mathrm{M}$ that produced by electrochemistry laboratory was measured by the secondary method using Jones Cell type D. Before used as a standard solution, the $\mathrm{RM}$ of $\mathrm{KCl} 1 \mathrm{M}$ must be ensured for their homogeneity and stability as required in ISO 17034:2016 [5]. The stability of RM depends on the suitability of the packaging [6]. The stability of packaging for the $\mathrm{RM}$ solution $(\mathrm{KCl})$ has been studied before, showing that a sealed ampoule is the most suitable packaging for EC RM [7]. But this type of packaging has disadvantages because a risk for substance to be contaminated with glass particles when the ampoules are opened [8].

Therefore, in this work, the stability of RM is evaluated by monitoring the effect of the type of packaging (HDPE and glass bottle) and storage temperature (at $25{ }^{\circ} \mathrm{C}$ and $40{ }^{\circ} \mathrm{C}$ ) for four weeks that specifies the duration and condition of transportation the RM to the end-user in Indonesia.

\section{EXPERIMENTAL SETUP}

\subsection{Materials}

Potassium chloride ( $\mathrm{KCl}$ analysis grade, $99.5 \%$ purity with molar mass $74.55 \mathrm{~g} / \mathrm{mol}$ ) was purchased from Merck, Germany. A CRM of the Primary standard solution with EC value $100 \mathrm{mS} / \mathrm{cm}$ at $25{ }^{\circ} \mathrm{C}$ (code CRM1714) was purchased from DFM. Demineralized water $0.055 \mu \mathrm{S} / \mathrm{cm}$ was produced from Thermo Scientific Barnstead Smart2pure water purification system used in all experimental runs.

\subsection{Preparation of $R M$ solution}

One batch of RM solution was prepared from $1 \mathrm{M}$ of $\mathrm{KCl}$. The preparation procedure was adopted from literature [9]. The procedure was repeated for 14 times with an approximate total volume of $28 \mathrm{~L}$. Then the solution was divided into 56 bottles of Nalgene ${ }^{\mathrm{TM}}$ Narrow-Mouth HDPE bottle (Figure 1a) and 56 bottles of DURAN® glass bottle with screw-capand pouring ring (PP, blue) (Figure $1 \mathrm{~b}$ ) with volume $250 \mathrm{~mL}$ of each bottle. The EC value of $\mathrm{KCl} 1 \mathrm{M}$ solution of each packaging was measured by the secondary method using Jones Cell type D. A statistical t-test was used to evaluate the significant difference of EC values for the two types of packaging. The EC values of the two types of packaging is no significant difference if $t_{\text {stat }}<t_{\text {critical }}[10]$.

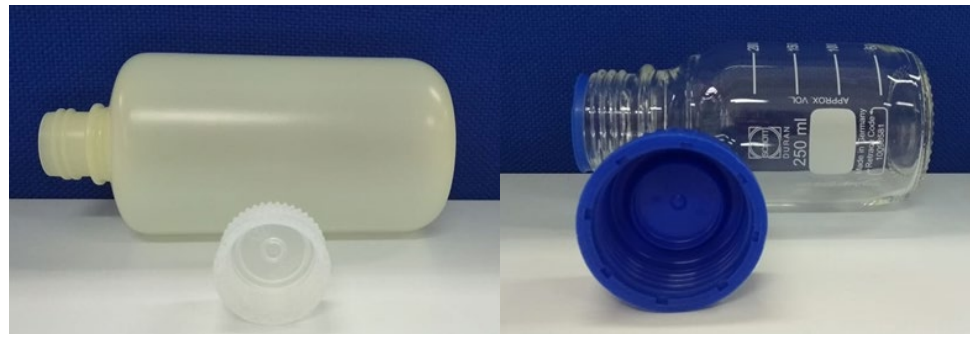

(a)

(b)

Fig. 1. a) Nalgene ${ }^{\mathrm{TM}}$ Narrow-Mouth HDPE bottle, b) DURAN® glass bottle with screw cap and pouring ring (PP, blue).

\subsection{Procedure of EC measurement}

The measurement of the EC value of RM for $\mathrm{KCl} 1 \mathrm{M}$ solution in HDPE and glass bottles were conducted by the secondary method. The systems for secondary method are depicted in Figure 2. This system was equipped with a cell D (purchased from ZMK, Germany). The cell D is a glass tube with two platinization electrodes having diameter of $20 \mathrm{~mm}$ and the distance of the two electrodes is $60 \mathrm{~mm}$. This cell has a cover plate, made from metal and grips to set the cell into the thermostatic bath (water bath Proline PV36 and Chiller DLK25, Lauda Germany) [11]. The temperature of measurement was measured using MKT50, Anton Paar Germany. The resistance of the $\mathrm{RM}$ for $\mathrm{KCl} 1 \mathrm{M}$ solution was measured using a precision LCR meter (8105G, GW-Instek Taiwan). The detailed of procedure was adopted from literature [9]. 


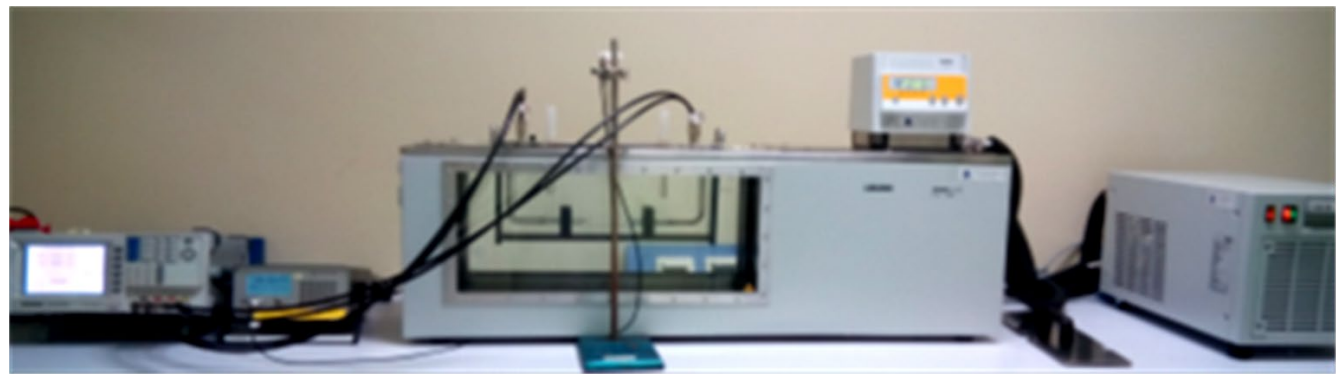

Fig. 2. The secondary EC measurement system [9].

Before calculating the $\mathrm{EC}$ value $(\kappa)$ of $\mathrm{RM}$ for $\mathrm{KCl} 1 \mathrm{M}$, the cell constant $\left(K_{\text {cell }}\right)$ of Jones cell type $\mathrm{D}$ must firstly be determined. This is in accordance with equation (1) [12].

$$
\kappa=K_{\text {cell }} \times G
$$

where $G$ in $\mathrm{mS}$ is conductance that reciprocal of the resistance $(R)$ in ohm $(\Omega)$ that described in equation (2) [13].

$$
G=\frac{1}{R}
$$

The cell constant is a factor for converting the measured conductance to conductivity [14]. Each cell has a different dimension of the electrodes. Therefore, each cell has a different cell constant that will be used in a different area of EC measurement [15]. In a secondary method, the cell constant is determined using a primary standard solution that traceable to SI [16]. In this study, CRM1714 from DFM was used as a primary standard solution. Therefore, this measurement is traceable to DFM. The cell constant $\left(K_{\text {cell }}\right)$ in $\mathrm{cm}^{-1}$ was calculated using equation (3) [17].

$$
K_{\text {cell }}=\frac{\kappa}{G}
$$

where $\kappa$ is the EC value of CRM1714 from the certificate $(100 \mathrm{mS} / \mathrm{cm})$ [18].

\subsection{Homogeneity test}

After the preparation, the $\mathrm{RM}$ of $\mathrm{KCl} 1 \mathrm{M}$ solution was evaluated for its homogeneity. It is important to verify that all bottles of RM for KCl $1 \mathrm{M}$ solution may identic with the same EC value [19]. In this homogeneity test, the EC value of $\mathrm{RM}$ for $\mathrm{KCl} 1 \mathrm{M}$ solution was determined by measuring the $\mathrm{KCl} 1 \mathrm{M}$ in both packaging types (HDPE and glass bottles) using Jones Cell type D with 10 bottles for each that randomly selected. Each measurement was conducted in two replicates. The F-test using a one-way analysis of variance (ANOVA) was then used to check the homogeneity of the $\mathrm{RM}$ for $\mathrm{KCl} 1 \mathrm{M}$ solution. The $\mathrm{RM}$ is categorized as a homogenous solution if the value of $F<F_{\text {critical }}$ [12].

\subsection{Effect of packaging types and temperature condition on the short-term stability}

Eight bottles of HDPE containing $250 \mathrm{ml}$ of $\mathrm{RM}$ for $\mathrm{KCl} 1 \mathrm{M}$ solution were randomly selected and stored at $25^{\circ} \mathrm{C}$ for 4 weeks. And, other 8 bottles of HDPE containing $250 \mathrm{~mL}$ of $\mathrm{RM}$ for $\mathrm{KCl} 1 \mathrm{M}$ solution were stored at $40{ }^{\circ} \mathrm{C}$ for 4 weeks. Every week, the stability of the RM for $\mathrm{KCl} 1 \mathrm{M}$ solution was monitored by measuring the $\mathrm{KCl}$ $1 \mathrm{M}$ solution in HDPE bottles ( 2 bottles per week). The stability of the RM for the $\mathrm{KCl} 1 \mathrm{M}$ solution was evaluated using linear regression analysis. The RM is categorized as stable if P-value for X Variable 1 more than 0.05 [12, $20,21]$. In a similar procedure, the stability of $\mathrm{RM}$ for $\mathrm{KCl} 1 \mathrm{M}$ solution in a glass bottle was also measured and the result is reported.

\section{RESULTS AND DISCUSSION}

\subsection{RM of $\mathrm{KCl} 1 \mathrm{M}$}

The $\mathrm{KCl} 1 \mathrm{M}$ solution is a common EC standard solution for the calibration of the conductivity meter with a value of $111 \mathrm{mS} / \mathrm{cm}$ at $25^{\circ} \mathrm{C}$ [22]. The KCI solution is a very stable salt and it has been recognized as an international calibration standard for conductivity measurement [23]. In this work, the $\mathrm{RM}$ of $\mathrm{KCl} 1 \mathrm{M}$ was in-house prepared at electrochemistry laboratory by keeping its traceable properties for end-user laboratories in Indonesia. Before determining the $\mathrm{EC}$ value of $\mathrm{KCl} 1 \mathrm{M}$, the cell constant of Jones Cell type D must be determined first to ensure 
the value of cell constant that will be used as a factor to calculate the EC value of $\mathrm{KCl} 1 \mathrm{M}$ [14]. The measurement result for the calculation of the cell constant of Jones Cell type D are tabulated in Table 1 [9]. From Table 1, it can be seen that the cell constant of Jones Cell type D is $1.5167 \mathrm{~cm}^{-1}$. Then, this cell constant was used to calculate the $\mathrm{EC}$ value of $\mathrm{RM}$ for $\mathrm{KCl} 1 \mathrm{M}$. The $\mathrm{RM}$ of $\mathrm{KCl} 1 \mathrm{M}$ is very important for any laboratory to keep their EC measurement traceable to the SI unit and to assure reliable and precise measurement results [24]. In addition, to keep its traceable to the SI unit, ISO 17034:2016 [5] requires that the RM should also show good homogeneity and stability properties.

Table 1. Result measurement for the calculation the cell constant.

\begin{tabular}{|c|c|c|}
\hline $\mathrm{f}(\mathrm{Hz})$ & $1 / \mathrm{f}\left(\mathrm{Hz}^{-1}\right)$ & Resistance $(\Omega)$ \\
\hline 120 & 0.0083 & 15.1788 \\
\hline 130 & 0.0077 & 15.1779 \\
\hline 140 & 0.0071 & 15.1771 \\
\hline 150 & 0.0067 & 15.1764 \\
\hline 160 & 0.0063 & 15.1759 \\
\hline 170 & 0.0059 & 15.1754 \\
\hline 200 & 0.0050 & 1741 \\
\hline 210 & 0.0048 & 1737 \\
\hline 330 & 0.0030 & 17.1707 \\
\hline 360 & 0.0028 & 15.1696 \\
\hline 480 & 0.0021 & 15.1668 \\
\hline Intercept value & $(\Omega)$ & 0.0659 \\
\hline \multirow{2}{*}{ Conductance $(G)$ using Eq. $(2)$} & $(\mathrm{S})$ & 65.9335 \\
\hline EC value of CRM1714 from certificate $(\kappa)$ & $(\mathrm{mS})$ & 100 \\
\hline Cell Constant $\left(K_{\text {cell }}\right)$ using Eq. $(3)$ & $(\mathrm{mS} / \mathrm{cm})$ & 1.5167 \\
\hline
\end{tabular}

\subsection{Homogeneity test}

It has been worldwide recognized that the homogeneity testing is a very important step to verify that all bottles as the packaging of RM solution have identical properties and to ensure that RM delivered to the end user laboratories are the same nominal value [25]. Thus, the RM of $\mathrm{KCl} 1 \mathrm{M}$ is evaluated for its homogeneity before used. The homogeneity of the RM for $\mathrm{KCl} 1 \mathrm{M}$ in both HDPE and glass bottles were tested and the testing results were used as the assigned value for $\mathrm{RM}$ of $\mathrm{KCl} 1 \mathrm{M}$. Table 2 and Table 4 list the measurement result of EC values for $\mathrm{KCl} 1$ $\mathrm{M}$ in glass and HDPE bottles.

Table 2. Result measurements of EC value for $\mathrm{KCl} 1 \mathrm{M}$ in glass bottles.

\begin{tabular}{|c|c|c|c|}
\hline \multirow{2}{*}{ Number of Bottle } & Result of Measurement, $(\mathrm{mS} / \mathrm{cm})$ & \multirow{2}{*}{$\begin{array}{c}\text { Average Value } \\
(\mathrm{mS} / \mathrm{cm})\end{array}$} \\
\cline { 2 - 3 } & 1 & 2 & 111.64 \\
\hline 16 & 111.63 & 111.65 & 111.62 \\
\hline 39 & 111.61 & 111.63 & 111.61 \\
\hline 35 & 111.61 & 111.62 & 111.61 \\
\hline 24 & 111.61 & 111.60 & 111.61 \\
\hline 03 & 111.61 & 111.62 & 111.61 \\
\hline 47 & 111.61 & 111.62 & 111.61 \\
\hline 22 & 111.61 & 111.61 & 111.61 \\
\hline 52 & 111.62 & 111.62 & 111.61 \\
\hline 30 & 111.60 & 111.62 & \\
\hline 55 & 111.60 & & \\
\hline $\begin{array}{l}\text { The assigned value for KCl 1 M in } \\
\text { a glass bottle }\end{array}$ & $111.62 \mathrm{mS} / \mathrm{cm}$ & & \\
\hline
\end{tabular}

From Table 2, it can be seen that the assigned value for $\mathrm{RM}$ of $\mathrm{KCl} 1 \mathrm{M}$ in a glass bottle is found to be $111.62 \mathrm{mS} / \mathrm{cm}$. Moreover, the homogeneity of $\mathrm{KCl} 1 \mathrm{M}$ was evaluated by F-test using one-way ANOVA from 10 bottles that have been randomly selected. The results are listed in Table 3. From the statistical calculation, it can be observed that the value of $\mathrm{F}$ (3.019815) is less than of $F_{\text {critical }}$ (4.413873), indicating that the $\mathrm{RM}$ of $\mathrm{KCl} 1 \mathrm{M}$ in the glass bottles are homogenous [12]. 
Table 3. One-way ANOVA of homogeneity testing for $\mathrm{RM}$ of $\mathrm{KCl} 1 \mathrm{M}$ in glass bottle.

\begin{tabular}{|l|c|c|c|c|c|c|}
\hline \multicolumn{1}{|c|}{ Source of Variation } & SS & df & MS & F & P-value & $F_{\text {critical }}$ \\
\hline Between Groups & 0.000337 & 1 & 0.000337 & 3.019815 & 0.099331 & 4.413873 \\
\hline Within Groups & 0.002011 & 18 & 0.000112 & & & \\
\hline Total & 0.002349 & 19 & & & & \\
\hline
\end{tabular}

Furthermore, the homogeneity testing of RM for $\mathrm{KCl} 1 \mathrm{M}$ in the HDPE bottle was also conducted using the same procedure with glass bottles as mentioned above. Several bottles (10 bottles) of HDPE bottle containing KCl $1 \mathrm{M}$ was randomly selected and measured and then results of EC values for $\mathrm{KCl} 1 \mathrm{M}$ in HDPE bottles are shown in Table 4. From Table 4, it is known that the assigned value for $\mathrm{KCl} 1 \mathrm{M}$ in $\mathrm{HDPE}$ bottle is $111.61 \mathrm{mS} / \mathrm{cm}$. An Ftest using one-way ANOVA against $10 \mathrm{HDPE}$ bottles containing $\mathrm{KCl} 1 \mathrm{M}$ was conducted for checking the homogeneity and the results are listed in Table 5. From Table 5, it can be observed that the value of F (0.296635) is less than $F_{\text {critical }}$ (4.413873). This result implies that the $\mathrm{KCl} 1 \mathrm{M}$ in HDPE bottles is homogenous [12].

From the studies, it was found that the assigned value of $\mathrm{KCl} 1 \mathrm{M}$ in both HDPE and glass bottles are $111.61 \mathrm{mS} / \mathrm{cm}$ and $111.62 \mathrm{mS} / \mathrm{cm}$, respectively. Then, the possible statistical difference between these two assigned values was assessed by using a t-test. The results of the t-test for the EC value of $\mathrm{KCl} 1 \mathrm{M}$ in both packaging types are shown in Table 6. It can be clearly seen that the two values having a very small difference. However, the t-test is required to determine for any significant difference between the means of the two group [26]. Table 6 shows that the $t_{\text {stat }}(1.39)$ is less than $t_{\text {critical }}(2.26)$, implying the EC value of the two types of packaging is not statistically significantly different [27]. In addition, the statistical test indicates that one batch of $\mathrm{KCl} 1 \mathrm{M}$ solution in both HDPE and glass bottle has a good homogeneity property.

Table 4. Result measurements of EC value for $\mathrm{KCl} 1 \mathrm{M}$ in HDPE bottles.

\begin{tabular}{|c|c|c|c|}
\hline \multirow{2}{*}{ Number of Bottle } & \multicolumn{2}{|c|}{ Result of Measurement $(\mathrm{mS} / \mathrm{cm})$} & $\begin{array}{l}\text { Average Value } \\
(\mathrm{mS} / \mathrm{cm})\end{array}$ \\
\cline { 2 - 4 } & 1 & 2 & 111.59 \\
\hline 18 & 111.59 & 111.59 & 111.60 \\
\hline 45 & 111.59 & 111.61 & 111.61 \\
\hline 50 & 111.61 & 111.60 & 111.61 \\
\hline 44 & 111.61 & 111.61 & 111.61 \\
\hline 54 & 111.60 & 111.62 & 111.63 \\
\hline 29 & 111.63 & 111.63 & 11.61 \\
\hline 11 & 111.61 & 111.60 & 11.61 \\
\hline 37 & 111.61 & 111.61 & 111.61 \\
\hline 22 & 111.61 & 111.61 & \\
\hline The assigned value for KCl $1 \mathrm{M}$ in HDPE bottle & $111.61 \mathrm{mS} / \mathrm{cm}$ & 111.61 & \\
\hline
\end{tabular}

Table 5. One-way ANOVA of homogeneity testing for $\mathrm{KCl} 1 \mathrm{M}$ in HDPE bottles.

\begin{tabular}{|l|c|c|c|c|c|c|}
\hline \multicolumn{1}{|c|}{ Source of Variation } & SS & df & MS & F & P-value & $F_{\text {critical }}$ \\
\hline Between Groups & $3.03 \mathrm{E}-05$ & 1 & $3.03 \mathrm{E}-05$ & 0.296635 & 0.592684 & 4.413873 \\
\hline Within Groups & 0.001841 & 18 & 0.000102 & & & \\
\hline Total & 0.001872 & 19 & & & & \\
\hline
\end{tabular}

Table 6. The t-test of EC values for $\mathrm{KCl} 1 \mathrm{M}$ in HDPE and glass bottles.

\begin{tabular}{|l|c|c|}
\hline & \multicolumn{1}{|c|}{ Glass bottles } & HDPE bottles \\
\hline Mean & 111.62 & 11.61 \\
\hline Variance & $8.17 \mathrm{E}-05$ & $1.59 \mathrm{E}-05$ \\
\hline Observations & \multicolumn{1}{|}{10} \\
\hline Hypothesized Mean Difference & 0 & \\
\hline df & 9 & \\
\hline$t_{\text {stat }}$ & 1.39 & \\
\hline$t_{\text {critical }}$ & 2.26 & \\
\hline
\end{tabular}




\subsection{Stability test}

The RM should not only have a good homogeneity property but also should sufficiently stable [28]. Stability is one of the key features of all RM. It is important that the value for each bottle of RM at the time of use is consistent with the stated value in the product certificate because the value of RM can change over time with various reasons [29]. Therefore stability testing is important way to determine the degree of instability of the RM after preparation and to confirm the stability of the material during storage, transportation and laboratory handling [6, 29]. There are two types of stability tests for RM i.e., long term and short-term stability. The long term stability is stability of RM during the period of validity under specified storage condition and short term stability is stability during transportation when RM is delivered to the customer [29]. In this work, the short term stability of RM for $\mathrm{KCl} 1$ $\mathrm{M}$ was conducted for two types of packaging (i.e. HDPE and glass bottle), then at different temperature conditions (i.e. $25^{\circ} \mathrm{C}$ and $40^{\circ} \mathrm{C}$ ) for 4 weeks. The results of $\mathrm{EC}$ measurement for $\mathrm{KCl} 1 \mathrm{M}$ in a glass bottle at storage temperature of $40^{\circ} \mathrm{C}$ are shown in Table 7 . Then, a regression analysis was used to evaluate the stability of $\mathrm{KC} 11$ $\mathrm{M}$ and the results are listed in Table 8 .

Table 7. EC measurement of $\mathrm{KCl} 1 \mathrm{M}$ in glass bottle that stored at $40{ }^{\circ} \mathrm{C}$.

\begin{tabular}{|c|c|}
\hline Week & Result of EC measurement, $(\mathrm{mS} / \mathrm{cm})$ \\
\hline 0 & 111.62 \\
\hline 1 & 111.61 \\
\hline 2 & 111.62 \\
\hline 3 & 111.63 \\
\hline 4 & 111.61 \\
\hline
\end{tabular}

Table 8. Regression analysis of $\mathrm{KC} 11 \mathrm{M}$ in glass bottle that stored at $40{ }^{\circ} \mathrm{C}$.

\begin{tabular}{|l|l|l|l|l|}
\hline & Coefficients & Standard Error & t-stat & P-value \\
\hline Intercept & 111.618 & 0.007483315 & 14915.58 & $6.65 \mathrm{E}-13$ \\
\hline X Variable 1 & $-1.42134 \mathrm{E}-15$ & 0.00305505 & $-4.7 \mathrm{E}-13$ & 1 \\
\hline
\end{tabular}

From Table 8 can be observed that the P-value for X variable 1 (1) is higher than 0.05 . It can be said that RM of $\mathrm{KCl} 1 \mathrm{M}$ in a glass bottle is stable at $40^{\circ} \mathrm{C}$ for 4 weeks $[12,20,21]$. It is because the glass bottle is made from borosilicate that has highly inert, high chemical resistance, inert behavior at high temperatures up to $500^{\circ} \mathrm{C}$ [30]. Therefore there is no reaction of $\mathrm{KCl} 1 \mathrm{M}$ in the glass bottle at $40^{\circ} \mathrm{C}$ and makes this solution stable. Then the EC measurement for $\mathrm{RM}$ of $\mathrm{KCl} 1 \mathrm{M}$ in a glass bottle that stored at $25^{\circ} \mathrm{C}$ is tabulated in Table 9 . Then, a regression analysis results for $\mathrm{KCl} 1 \mathrm{M}$ in glass bottles stored at $25^{\circ} \mathrm{C}$ is listed in Table 10 .

Table 9. EC measurement of $\mathrm{KCl} 1 \mathrm{M}$ in glass bottle that stored at $25^{\circ} \mathrm{C}$.

\begin{tabular}{|c|c|}
\hline Week & Result of EC measurement, $(\mathrm{mS} / \mathrm{cm})$ \\
\hline 0 & 111.62 \\
\hline 1 & 111.61 \\
\hline 2 & 111.62 \\
\hline 3 & 111.61 \\
\hline 4 & 111.61 \\
\hline
\end{tabular}

Table 10. Regression analysis of $\mathrm{KC} 11 \mathrm{M}$ in glass bottle that stored at $25^{\circ} \mathrm{C}$.

\begin{tabular}{|l|l|l|l|l|}
\hline & Coefficients & Standard Error & t-stat & P-value \\
\hline Intercept & 111.618 & 0.004 & 27904.5 & $1.01 \mathrm{E}-13$ \\
\hline X Variable 1 & -0.002 & 0.001632993 & -1.22474 & 0.308068 \\
\hline
\end{tabular}

From Table 10, it can be seen that $\mathrm{P}$-value for $\mathrm{X}$ variable $1(0.308068)$ is higher than 0.05 . This value indicates that $\mathrm{RM}$ of $\mathrm{KCl} 1 \mathrm{M}$ in glass bottles is stable at $25^{\circ} \mathrm{C}$ for 4 weeks. Then, the stability of $\mathrm{KCl} 1 \mathrm{M}$ in HDPE bottles was evaluated its stability at $40^{\circ} \mathrm{C}$ and $25^{\circ} \mathrm{C}$ for 4 weeks. The $\mathrm{EC}$ measured values for $\mathrm{KCl} 1 \mathrm{M}$ in $\mathrm{HDPE}$ bottles at $40^{\circ} \mathrm{C}$ are listed in Table 11.

Table 11. EC measurement of $\mathrm{KCl} 1 \mathrm{M}$ in HDPE bottle that stored at $40^{\circ} \mathrm{C}$.

\begin{tabular}{|c|c|}
\hline Week & Result of EC measurement, $(\mathrm{mS} / \mathrm{cm})$ \\
\hline 0 & 111.61 \\
\hline 1 & 111.62 \\
\hline
\end{tabular}




\begin{tabular}{|l|l|}
\hline 2 & 111.62 \\
\hline 3 & 111.63 \\
\hline 4 & 111.63 \\
\hline
\end{tabular}

It can be seen from Table 11 that the EC values increase with time. In this regard, stability is required to be evaluated by using regression analysis. This evaluation is aimed to ensure the stability property of the $\mathrm{KCl} 1 \mathrm{M}$ solution since increasing the EC value (Table 11) is questionable. The results of regression analysis are listed in Table 12.

Table 12. Regression analysis of $\mathrm{KC1} 1 \mathrm{M}$ in HDPE bottle that stored at $40{ }^{\circ} \mathrm{C}$.

\begin{tabular}{|l|l|l|l|l|}
\hline & Coefficients & Standard Error & t-stat & P-value \\
\hline Intercept & 111.612 & 0.002449 & 45565.41 & $2.33 \mathrm{E}-14$ \\
\hline X Variable 1 & 0.005 & 0.001 & 5 & 0.015392 \\
\hline
\end{tabular}

From Table 12, it can evidence that P-value for X variable $1(0.015392)$ is less than 0.05 . It is indicated that the $\mathrm{RM}$ of $\mathrm{KCl} 1 \mathrm{M}$ in HDPE bottles is unstable at $40^{\circ} \mathrm{C}$ for 4 weeks. The instability might be caused by the evaporation of $\mathrm{KCl}$ solution at $40^{\circ} \mathrm{C}$ or leaching of the HDPE bottles. Evaporation occurs through the space between the bottle and the cap, usually resulting from the cap relaxing and loosening with time. Leaching of ions from the container or reactions of the solution with the container may also occur. All these effects cause the solutions of $\mathrm{KCl}$ unstable. This result is in agreement with a previous study [31] because evaporating and leaching may cause the conductivity of the solution lead to increase with time. Then, the results of $\mathrm{EC}$ measurement values for stability study of $\mathrm{KCl} 1$ $\mathrm{M}$ in HDPE bottles at $25^{\circ} \mathrm{C}$ are shown in Table 13 . Then, a regression analysis results for $\mathrm{KCl} 1 \mathrm{M}$ in HDPE bottles stored at $25^{\circ} \mathrm{C}$ is listed in Table 14 .

Table 13. EC measurement of $\mathrm{KCl} 1 \mathrm{M}$ in HDPE bottle that stored at $25^{\circ} \mathrm{C}$.

\begin{tabular}{|c|c|}
\hline Week & Result of EC measurement, $(\mathrm{mS} / \mathrm{cm})$ \\
\hline 0 & 111.61 \\
\hline 1 & 111.61 \\
\hline 2 & 111.61 \\
\hline 3 & 111.61 \\
\hline 4 & 111.60 \\
\hline
\end{tabular}

Table 14. Regression analysis of $\mathrm{KC} 11 \mathrm{M}$ in HDPE bottle that stored at $25^{\circ} \mathrm{C}$.

\begin{tabular}{|l|l|l|l|l|}
\hline & Coefficients & Standard Error & t-stat & P-value \\
\hline Intercept & 111.612 & 0.002828 & 39460.8 & $3.59 \mathrm{E}-14$ \\
\hline X Variable 1 & -0.002 & 0.001155 & -1.73205 & 0.18169 \\
\hline
\end{tabular}

From Table 14, the data indicates that the $\mathrm{P}$-value for $\mathrm{X}$ variable 1 is 0.18169 . This value is higher than 0.05 . It is indicating that $\mathrm{RM}$ of $\mathrm{KCl} 1 \mathrm{M}$ is stable when stored in $25^{\circ} \mathrm{C}$ for 4 weeks.

\section{CONCLUSIONS}

As much as $28 \mathrm{~L}$ of $\mathrm{RM}$ for $\mathrm{KCl} 1 \mathrm{M}$ as a standard solution for calibration of the conductivity meter has been made by electrochemistry laboratory - chemical metrology Indonesia. This solution was homogenously packaged in HDPE and glass bottle, having conductivity values were $111.61 \mathrm{mS} / \mathrm{cm}$ and $111.62 \mathrm{mS} / \mathrm{cm}$, respectively. It was stable when stored at $25^{\circ} \mathrm{C}$. Then, the glass bottle was found to be the best packaging of $\mathrm{KCl} 1 \mathrm{M}$ for transportation at $40^{\circ} \mathrm{C}$ for 4 weeks.

\section{ACKNOWLEDGEMENTS}

The authors express their sincere appreciation to the Research Centre for Metrology - Indonesian Institute of Sciences (LIPI) for funding this research and thanks to Centre for Research and Human Resources and Development - National Standardization Agency of Indonesia (PUSRISBANG SDM - BSN). 


\section{REFERENCES}

[1] ISO Technical Committees, ISO Guide 30:2015 in reference materials - selected terms and definitions, ISO copyright, Switzerland, 2015.

[2] Eurachem, The selection and use of reference materials, in a basic guide for laboratories and accreditation bodies, Eurachem, Europe, 2002.

[3] EEE-RM Working Group., The selection and use of reference materials, European accreditation, Europe, 2003.

[4] Breuel, U., Werner, B., Jehnert, D., Metrology in chemistry for pH and electrolytic conductivity traceability dissemination, Chimia, vol. 63, 2009, p. 643-646.

[5] ISO Technical Committees., ISO 17034-general requirements for the competence of reference material producers, ISO copyright, Switzerland, 2016.

[6] Faure, U., Wagstaffe, P.J., Stability of reference materials, Fresenius journal of analytical chemistry, vol. 345, 1993, p. 124-126.

[7] Shreiner, R.H., Stability of standard electrolytic conductivity solutions in glass containers, Journal of research national institute of standards and technology, vol. 107, 2002, p. 393-399.

[8] WHO Expert Committee, Annex 3: general guidelines for the establishment, maintenance and distribution of chemical reference substances, Geneva, 2006.

[9] Hindayani, A., Zuas, O., Elishian, C., Aristiawan, Y., Hamim, N., Uncertainty estimation for the measurement of electrolytic conductivity by secondary method using cell type D, Periódico tchê química, vol. 16, 2019, p. 911919.

[10] Kim, T.K., T test as a parametric statistic, Korean journal anesthesiology, vol. 68, 2015, p. 540-546.

[11] Breuel, U., Werner, B., Spitzer, P., Jensen, H.D., Experiences with novel secondary conductivity sensors within the german calibration service (DKD). NCSLI measure, vol. 3, 2008, p. 32-36.

[12] Fraga, I.C. S., Lopes, J.C., Sobral, S.P., Ribeiro, C.M., Certification of a low value electrolytic conductivity solution using traceable measurements, Accreditation and quality assurance, vol. 18, 2013, p. 99-104.

[13] Breuel, U., Garbotz, N., Werner, B., Experiences with novel secondary conductivity sensors within the German calibration service (DKD), NCSL International workshop and symposium, Saint Paul, Minnesota, 2007.

[14] Radiometer analytical SAS., Conductivity theory and practice, France, 2004.

[15] Slovacek, D., Measurement of conductivity, Hach Company, Loveland, 1998.

[16] Breuel, U., Werner, B., Spitzer, P., Jensen, H. D., Experiences with novel developed secondary conductivity sensors within the German calibration service (DKD), NCSL international workshop and symposium, 230th PTB Seminar conductivity and salinity, Braunschweigh, 2007.

[17] Wu, Y.C., Berezansky, P. A., Low electrolytic conductivity standards. Journal of research national institute of standards and technology, vol. 100, 1995, p. 521-527.

[18] Snedden, A., Certificate of analysis certified reference material reference solution of electrolytic conductivity $100 \mathrm{mS} / \mathrm{cm}$, DFM, Denmark, 2017.

[19] Pauwels, J., Lamberty, A., Schimmel, H., Homogeneity testing of reference materials. Accreditation and quality assurance, vol. 3, 1998, p. 51-55.

[20] LGC, EU-Indonesia trade support programme II (TSP2): standard relating to setting up a reference material producers accreditation system-ISO Guide 35-stability study, England, 2013.

[21] De Souza, V., Rodrigues, J.M., Bandeira, R.D.C., Valente, L.A.N., Sousa, M.V.B., Da Silva, V.F., Da Silva, R.A.L., Evaluation of stability of ethanol in water certified reference material: measurement uncertainty under transport and storage conditions. Accreditation and quality assurance, vol. 13, 2008, p. 717-721.

[22] OIML, OIML R 56: standard solutions reproducing the conductivity of electrolytes, Bureau international de metrologie legale, Prancis, 1981.

[23] DB Water Technologies., $\mathrm{KCl}$ standard solution, https://www.glycolfeeder.com/searchresults.asp?cat=43, Accessed 14/01/2019.

[24] Brinkmann, F., Dam, N.E., Deak, E., Durbiano, F., Ferrara, E., Fükü, J., Jensen, H. D., Mariassy, M., Shreiner, R.H., Spitzer, P., Sudmeier, U., Surdu, M., Vyskocil, L., Primary methods for the measurement of electrolytic conductivity, Accreditation and quality assurance, vol. 8, 2003, p. 346-353.

[25] Quevauviller, P., Requirements for production and use of certified reference materials for speciation analysis: a european commission perspective, Spectrochimica acta, part B, vol. 53, 1998, p. 1261-1279.

[26] Investopedia, T-test, https://www.investopedia.com/terms/t/t-test.asp, Accessed 14/01/2019.

[27] Minitab., Using the t-value to determine whether to reject the null hypothesis, https://support.minitab.com/enus/minitab-express/1/help-and-how-to/modeling-statistics/regression/supporting-topics/regression-models/usingthe-t-value-to-determine-whether-to-reject-the-null-hypothesis/, Accessed 14/01/2019. 
[28] Van der Veen, A.M.H., Linsinger, T.P.J., Lamberty, A., Pauwels, J., Uncertainty calculations in the certification of reference materials: 3. stability study, Accreditation and quality assurance, vol. 6, 2001, p. 257263.

[29] ISO Technical Committees, ISO Guide 35:2017 in reference materials - guidance for characterization and assessment of homogeneity and stability, ISO copyright, Switzerland, 2017.

[30] Schoot Duran, Laboratory glass bottles and screw caps, https://www.schott.com/d/uk/c260afa3-294c-41eea7eb-1855e88cdfee/1.0/bottles_caps.pdf, Accessed 10/01/2019.

[31] Shreiner, R.H., Pratt, K.W., Standard reference materials: primary standards and standard reference materials for electrolytic conductivity, NIST special publication 260-142, Washington, 2004. 